Environment, Biodiversity \& Soil Security
(EBSS)
http://jenvbs.journals.ekb.eg//

\title{
Agro-Pollutants and Their Nano-Remediation from Soil and Water: A Mini-Review
}

Hassan El-Ramady ${ }^{1}$, Ahmed El-Henawy ${ }^{1}$, Megahed Amer ${ }^{2 *}$, Alaa El-Dein Omara $^{3}$, Tamer Elsakhawy ${ }^{3}$, Abdel-Moety Salama ${ }^{4}$, Ahmed Ezzat ${ }^{4}$, Ali ElShereif ${ }^{4}$, Mohammed El-Mahrouk ${ }^{4}$ and Tarek A. Shalaby ${ }^{4,5}$

${ }^{1}$ Soil and Water Dept., Faculty of Agriculture, Kafrelsheikh University, Egypt

${ }^{2}$ Soils Improvement Dept., Soils, Water and Environment Research Institute (SWERI), Sakha Station, Agricultural Research Center (ARC), 33717 Kafr El-Sheikh, Egypt

${ }^{3}$ Agriculture Microbiology Department, Soil, Water and Environment Research Institute (SWERI), Sakha Agricultural Research Station, Agriculture Research Center (ARC), 33717 Kafr El-Sheikh, Egypt

${ }^{4}$ Horticulture Dept., Faculty of Agriculture, Kafrelsheikh University, Kafr El-Sheikh 33516, Egypt

${ }^{5}$ Arid-land Agriculture Department, College of Agricultural and Food Sciences, King Faisal University, Al-Ahsa; KSA

$\mathbf{T}$ HE human activities include the agricultural, industrial and other activities. The agricultural sector is considered the main source for our life's supplies. However, the agricultural activities or practices might result many pollutants such as applied mineral fertilizers, pesticides, effluents from domestic and industrial sewages and vehicular emissions. Therefore, a remediation to remove or decrease the pollutants in soil and water is needed for the environment protection. This remediation has several classic strategies several years ago, but a promising and new approaches have been established particularly nano-remediation. This nano-remediation depends on the applied nanomaterials in removing pollutants from soils and water through nano-bioremediation and nano-phytoremediation. The most important nanomaterials that have potential in removing pollutants from contaminated soils and water are nano-silica, nano-zero-valent of iron, nano-sized iron sulfide particles, nano- $\mathrm{ZnO}$ and others. However, many challenges or open questions are still needing a justification because using nanomaterials in higher concentrations are toxic to plants and agro-environment. Are these nanomaterials stable under environmental conditions or will be converted into toxic ones or still need to be identified for sustainable nano-remediation? Is there any possibility to enter the nanomaterials or other toxic compounds the food chain through these plants? Therefore, a lot of further research is needed concerning the nano-remediation in removal the agro-pollutants.

Keywords: Nano-phytoremediation, Nano-bioremediation, Nano-sized ironsulfide particles.

\section{Introduction}

Agriculture is considered one of the most important human activities, which represents the main source for food, feed, fuel and fiber. This activity may result a lot of environmental problems particularly under the excessive use of pesticides and mineral fertilizers. Hence, the agricultural pollution may refer to different agricultural practices, which result in the degradation or pollution of the agroecosystems and cause a damage to the human health(Khan et al. 2020). Different sources of agro-pollution could be considered rangingfrom a single discharge point (point source pollution) to nonpoint source pollution (from more diffuse and landscape-level sources) as reported by Zazai et al. (2018). The main anthropogenic sources of

\footnotetext{
"Corresponding author: E-mail: megahedamer3@gmail.com

Authors' Emails: hassan.elramady@agr.kfs.edu.eg; aelhenawy@agr.kfs.edu.eg; alaa.omara@yahoo.com; drelsakhawyg@gmail.com; abdelmoety.salama@gmail.com; Ahmed.kassem@agr.kfs.edu.eg; aelshereif@agr.kfs.edu.eg; threemelmahrouk@yahoo.com; tshalaby@kfu.edu.sa Received 26/10/2020; Accepted 16/11/2020 
soil pollution with toxicmetal and/or metalloids include pesticides, fertilizers, effluents from sewage from domestic and industrial sources, industrial activities, and vehicular emissions (Souza et al. 2020). Several studies have been published concerning pollution of soil and water from different pesticides and/or mineral fertilizers (e.g., Gupta et al. 2018; Saratovskikh 2020; Tran et al. 2020).

The remediation of polluted soils and water was and still one of the critical environmental issues, which means the removal of pollutants from soil and water using different strategies such as fungi ormyco-remediation (Butu et al. 2020), the cultivated plants by phytoremediation (Khan et al. 2020), earthworms or vermi-remediation (Karimi et al. 2020; Lacalle et al. 2020; Zeb et al. 2020), or soil micro-organisms by bioremediation (Kalsi et al. 2020), or by using some biosorbent materials like biochar (Wang et al. 2021), fly ash and organic fertilizers ( $\mathrm{Hu}$ et al. 2020), humic substances (Dong et al. 2021) and nanomaterials through green remediation (Yin et al. 2021) or combined remediation (Gu et al. 2020). Agricultural soil could be contaminated by several pollutants such as heavy metals (Hu et al. 2020), poly- and perfluoroalkyl substances (Bolan et al. 2021), and microplastics (Kumar et al. 2020a). This remediation could be achieved through different mechanisms such as phytoextraction (Yu et al. 2020), bioaugmentationand bio-stimulation (Lacalle et al. 2020),immobilization (Chen et al. 2020), biodegradation (Krohn et al. 2021), and vermi-accumulation, vermi-transformation and vermi-degradation in case of earthworms (Zeb et al. 2020).

Concerning the nanomaterials, already used in soil and water remediation, they may include nanophytoremediation (Srivastav et al. 2018; Romeh and Saber 2020), nano-bioremediation (Singh et al. 2020), nano- $\mathrm{Fe}_{3} \mathrm{O}_{4}$ (Tran et al. 2020), nano-FeS coated humic acid complex (Tan et al. 2020), nano zero-valent iron (Gamallo et al. 2020), nano-hydroxyapatite (Liao and Yang 2020), nano zeolite (Liu et al. 2020), nano zero-valent iron (Lv et al. 2020; Peng et al. 2020), ZnO-nanoparticles (Ahmad et al. 2019), nano- $\mathrm{TiO}_{2}$ (Sundararaghavan et al. 2020), stabilized nanoparticles (Sarkar et al. 2019; Cai et al. 2020), and nano-silica (Moameri and Khalaki 2019; Cao et al. 2020; Wang et al. 2020b).

Therefore, this review is an attempt to highlight the agricultural pollutants, its sources andits nanomanagement using the common nanomaterials. The nano-remediation of agri-pollutants also will be evaluated through different remediation methods including nano-bioremediation and nanophytoremediation.

\section{Agro-pollutants and their sources}

Agricultural pollution is a global environmental concern, which is mainly caused by the application of many farming inputs (likepesticides and fertilizers) and many practices such asthe excessive tillage of the soil and runoff process. Agricultural pollutants may involve the excessive amounts of phosphate and nitrate, the inorganic toxicants like heavy metals and organic compounds like pesticides. These agro-pollutants pose a great threat tothe biological or eco-system because of their high toxicities. The agro-pollution has negative impacts on soils, water, and air because it is not a single stressor or static component (Khan et al. 2020). This agro-pollution also has an adverse impacton the surrounding environment compartments including all living organism such as microorganisms, plants, animals and humans. These adverse effects of agropollution may include, but not limited to,the algal bloom due to eutrophication phenomena (Lin et al. 2020), rashes and other skin problems, respiratory diseases and neurological disorders due to inhaling polluted air (Shigaki 2020), kidney, liver and stomach problems and cancer due to swimming and drinking of polluted water (Borah et al. 2020). The high levels of nitrates in drinking water could cause the blue baby syndromein infants, which is often fatal (Khan et al. 2020). Several studies have focused on the agro-pollutants and their sources such as Kumwimba et al. (2018), Venier et al. (2019), Ahamad et al. (2020), Lee et al. (2020), Madhav et al. (2020), Bhuiyan et al. (2021), Kim et al. (2021), Yang et al. (2021), and Xiao et al. (2021).

\section{Nano-remediation of agro-pollutants}

Due to the anthropogenic activities in agriculture sector, several compounds or pollutants have been proven to be harmful for the agro-ecosystems, which include the release fertilizers, pesticides, heavy metals, halogenated and phenolic compounds (Ken and Sinha 2020). Several remediation methods have been established for treating different pollutants or contaminants. The remediation processes have their own cons and pros. The sustainable technologies of environmental cleanup have mainly a concern about two most important factors including ecotoxicity and cost effectiveness. Different remediation methods could be handled including bioremediation, phytoremediation and nano-remediation. Due to their sustainable, economic nature and ecofriendly, the 
nanomaterials-based adsorption and simultaneous redox degradation have become very popular to scientific community (Ken and Sinha, 2020).

\subsection{Nano-bioremediation}

Based on the increasing rate inurbanization, industrialization and modernization, the universe has brought down unsustainable pollution load on its environment. The toxic pollutants have been increased with alarming level in the environment, which have deteriorated the environment quality, disturbed the ecosystem and adversely impacted human health (Singh et al. 2020a). Bioremediation could be defined according to the United States Environmental Protection Agency (USEPA) "treatment that uses naturally occurring organisms tobreak down hazardous substances into less toxic or nontoxic substances" (Singh et al. 2020a). Bioremediation could be achieved essentially using the microorganisms in remediation of the pollutants present in water and soil matrices (Saxena et al. 2019; Halecký and Kozliak 2020). It is worth mention that different modern bioremediation approaches could be applied through using biosurfactants, emulsifiers, enzymes, biopesticides and Genetically Modified Organisms (GMOs) (Halecký and Kozliak, 2020).

The benefits could be maximized through using both nanotechnology and bioremediation together to achieve a remediation, making the process more efficient, less time taking and environment friendly than the individual processes (Singh et al. 2020a). Therefore, nano-bioremediation (NBR) is one of such kind of methods, which exploits the benefits of nanomaterials together with advantages of bioremediation,received a lot of concern in the past few years. Nano-bioremediation could be defined as "NBR is the removal of environmental pollutants from contaminatedsites using nanoparticles formed by bacteria, algae, actinomycetes, fungi, andplants, by the help of nanotechnology" (Mallikarjunaiah et al. 2020). NBR is a method by which nanomaterials could use in removing different contaminants from environmental matrices with biological processes or selected microbial species (Semerád et al. 2020; Singh et al. 2020a; Shahi et al. 2021). Very recently, an increasing concern on nano-bioremediation has been reported by many researchers depending on the purpose of application as follows:

1- Čvančarová et al. (2020) studied the nanobiosensors or nano-biocatalysts as nanobioremediation for rapid developing, detecting and monitoring different pollutants in the environmentthrough investigating the enzyme- based nanomaterials in bioremediation process,

2- Gamallo et al. (2020) studies nano-based technologies for soil remediation through the application of nanomaterials during soil remediation,

3- Kalia and Singh (2020) investigated the benefits of myco-remediation and its application of fungusnanoparticles bio-nanoconjugate to remediate the syntheticdye pollutants in wastewaters and land contaminated with the effluent of textile industries,

4- Mallikarjunaiah et al. (2020) studied the application of nanotechnology in the heavy metals'bioremediation from wastewater,

5- Pandit et al. (2020) reported about the bio-nano approaches as sustainable and green treatment technology for textile effluent challenges,

6- Omran (2021) handled the lethal impacts of industrialization via sustainable and green microbial removing of hazardous pollutants and the nano-bioremediation,

7- Semerád et al. (2020) presented the combined technology using both nano-remediation (nanoscale zero-valent iron) and bioremediation for in situ heavy metal (Cr, VI) removal and de-chlorination of chlorinated solvents,

8- Sinha et al. (2020) reported about the nanobioremediation technologies for potential application in the cleanup of the environment,

9- Singh et al. (2020a) studied the nanobioremediation and its applications, reducing the pollutant concentrations. This technique brings many benefits of both bioremediation and nanotechnology together to achieve a remediation in less time taking, more efficient and eco-friendly technique compared to the individual processes,

10- Singh et al. (2020b) discussed the nanobioremediation as an emerging approach for a cleaner environment and the nanotechnology based alternative treatment strategies for efficient and sustainable bioremediation and biodegradation,

11- Sharma and Pandey (2020) reported about nano-sorbents-assistedmicrobial bioremediation of hazardous petroleumhydro carbons through various adsorbents and microbial products such as biosurfactant and catalytic enzymes asthe major contributions in the field of bioremediation of hazardous petroleum hydrocarbons,

12- Sudhakar et al. (2020) studied different nanomaterials and their engaged mechanisms for bioremediation for heavy metals removal from water and soil resources,

13- Yogalakshmi et al. (2020) studied the current know-how of nanoparticles as a carrier for

Env. Biodiv. Soil Security Vol. 4 (2020) 
several enzymes for the degradation of pollutants present in textile wastewater and the role of these nanoparticles in removing of dyes,

14- Agrawal and Verma (2021) reported about using nanoparticles in removing pollutants from soil and water, and

15- Shahi et al. (2021) studied the nanobioremediation of environmental contaminants through its applications, challenges, and future prospects. The combination of nanotechnology with biotechnology is considered a promising approach for environmental remediation. Nanomaterials could be used directly or it could be used in combination with many microbes or microbial enzymes.

\subsection{Nano-phytoremediation}

Phytoremediation could be defined as "a green technology in which plants namely hyperaccumulators and their associated microbes are used to remediate the contaminated site to safeguard the environment" as reported by Saxena et al. (2019). The phytoremediation process has many mechanisms by which plants could remove the pollutants from soil or water through the accumulation, translocation and degradation of the toxicants such as metals, pesticides, hydrocarbons, and chlorinated solvents (Kumar et al. 2020b). This process mainly includes five mechanisms including phytoextraction / phytoaccumulation, phyto stabilization, phytodegradation, phytovolatilization, rhizo-filtrationand phyto-stimulation (Nasr 2019; Kanwar et al. 2020). The phytoremediation process also could be improved based on the partnership between plant and microbes, which has a great approach in removing several groups of pollutants from the different environmental matrix. This partnership is useful for both plants and microbes, where plants give shelter and nutrients/food to their adjacent endophytic and rhizospheric microbes. Meanwhile, the microbes, support plant growth by detoxifying and degrading the pollutants (Nwadinigwe and Ugwu 2018; Kumar et al. 2020b). There are enormous reports present in the literatures that showed the utility of plants for the removal of different pollutants from contaminated locations (He et al. 2019; Nasr 2019; Mishra et al. 2019; Kanwar et al. 2020; Lee et al. 2020; Yang et al. 2020; Yu et al. 2020; Raj and Maiti 2021; Verma and Rawat, 2021).

It is well known that, nanoparticles exhibit a number of special properties such as small enough to generate quantum effects, high surfacetovolume ratio, and unique physico-chemical properties, which explain why nanoparticles are getting an increasing interest in several fields of science, cosmetics, engineering, drug delivery, pharmaceuticals, and also in environmental remediation (Kumar et al. 2020b; Puthukkara et al. 2020). Under the umbrella of environmental remediation, several types of nanoparticles such as metals (Fe, $\mathrm{Ni}, \mathrm{Pd}, \mathrm{Zn}$, etc.), metal oxides $\left(\mathrm{TiO}_{2}\right.$, $\mathrm{Fe}_{2} \mathrm{O}_{3}, \mathrm{Fe}_{3} \mathrm{O}_{4}, \mathrm{MnO}_{2}, \mathrm{ZnO}$, etc.) and bi-metallic $(\mathrm{Cu} / \mathrm{Ni}, \mathrm{Fe} / \mathrm{Ag}, \mathrm{Pd} / \mathrm{Fe}$, etc.) nanoparticles have been used successfully for the degradation/removal of wide array of different pollutants. Concerning the mechanism of nano-particle-mediated remediation, it generally could happen through the following processes reduction/oxidation, ab/adsorption, catalytic degradation, precipitation, and co-precipitation (Wang et al. 2019a). It is well known also that, the cleanup process of pollutants is called as remediation, called a bioremediation or phytoremediation if a biological agent or plant species is involved in the removal of the pollutant/s, respectively. The integration of either of these previous methods with nanotechnology has been proved as an effective alternative to the existing traditional methods of remediation, which then called nano-bioremediation and nano-phytoremediation (Nwadinigwe and Ugwu 2018; Srivastav et al. 2018; Khan et al. 2020; Ebrahimbabaie et al. 2020). The potential of nanoparticles used for phytoremediation may be characterized with the following items: (1) enhancing the phytoremediation process itself, (2) increasing the germination, seedling, root-shoot elongation, plant height and its biomass, (3) increasing phyto-hormones (e.g., abscisic acid, indole acetic acid and gibberellin) or enzymes production in plant, (4) increasing the nutrients bioavailability for plants, and (5) capability to bind pollutants as well as these nanoparticles should be non-toxic materials (Kumar et al. 2020b).

Although plants may excrete toxic matter, there is a chance of nanomaterials to enter the food chain through these plants. The major challenge facing the nano-phytoremediation process is how to dispose the accumulated of heavy metals in plants, as they are considered toxic wastes (Verma et al. 2021). Several studies have been published on nano-phytoremediation to focus on different case studies of remediation including the following investigations:

1- Nano-phytoremediation is a combined technology between phytotechnology and nanotechnology for remediation of polluted environments. These combined techniques could allow pollutants to be degraded quickly and effectively under natural environmental conditions (Jesitha and Harikumar 2018), 
2- The applications of nano-phytoremediation have reported, which has many environmental benefits, and could be divided into three categories including remediation and treatment, sensing and detection and pollution prevention (Nwadinigwe and Ugwu 2018),

3- Nano-phytoremediation and its application for water pollution (Bhati and Rai, 2018) and soil environment (Srivastav et al. 2018),

4- This investigation studied a combination of remediation techniques on polluted soil with heavy metals $(\mathrm{Cu}, \mathrm{Cd}$ and $\mathrm{Pb})$ including the phytoremediation using white willow (Salix alba L.), and soil amendment with nano-sized zerovalent iron and rhizosphere microorganisms including the arbuscular mycorrhizal fungus, Rhizophagus irregularis and Pseudomonas fluorescens (Mokarram-Kashtiban et al. 2019),

5- The role of nano-hydroxyapatite in immobilization of $\mathrm{Pb}$ in the ryegrass rhizosphere soil, which contaminated with $\mathrm{Pb}$ (1200 mg kg-1) by changing the rhizosphere $\mathrm{pH}$ to the acid-soluble and reducible $\mathrm{Pb}$ concentrations (Liang et al. 2019),

6- Nanobiotechnology approach could be used in remediation the environmental hazards generated from industrial wastes. The future application of nanoparticles-linked bioremediation may include the application of engineered polymeric nanoparticles and single-enzyme nanoparticles inpollution of soils and hydrophobic contaminants in water, respectively (Gudeppu et al. 2019),

7- Study the phytoremediation of engineered nanoparticles (ENPs) using aquatic plants through their mechanisms and practical feasibility, the common types of ENPs in current use, their transformations in aquatic systems, the potential of micro-organisms in supporting plant growth and promoting plant uptake as well asthe recent findings in phytoremediation of ENP-affected water (Ebrahimbabaie et al. 2020),

8- Using Erigeron annuus (L.) Pers. plants combined with Triton X-100 (1000 mg kg-1) and nano- $\mathrm{SiO}_{2}\left(500 \mathrm{mg} \mathrm{kg} \mathrm{kg}^{-1}\right.$ ) were investigated to remove polycyclic aromatic hydrocarbons (PAHs) from soil. This study demonstrated that Triton $\mathrm{X}-100$ combined with nano- $\mathrm{SiO}_{2}$ could protect cultivated plants through alleviating the stress of PAHs, and could provide a means for improving phytoremediation of the PAH polluted soils (Zuo et al. 2020),

9- The co-application of plant growth-promoting bacteria (PGPR) and nano-scale zero-valent iron (up to $1000 \mathrm{mg} \mathrm{kg}^{-1}$ ) to promote phytoremediation of antimony polluted soil was investigated by Trifolium repens plants, where the combined use of plant in accompany with nanomaterials of iron and PGPR have recorded a great impact in removing of antimony from soil (Zand et al. 2020),

10- Combining classic methodologies of applied nanomaterials for soil remediation with the new approach of the techniques to improve the efficiency of remediation and using one technique for remediating more than one pollutant (Souza et al. 2020),

11- A combined usage of nano zero valent iron and black mangrove (Avicennia germinans), could be implemented for the remediation a contaminated wetland soils with $\mathrm{Cd}, \mathrm{Pb}$ and As. This phyto-nanoremediation process was evaluated for a period of 5 months using contaminated soil from Puerto Rico (Soto-Hidalgo et al. 2020), and

12- A comprehensive chapter discussed the role of nanoparticle-mediated phytoremediation, emphasizing on the role of nanoparticles in protecting plants from the oxidative stress and mimic enzymes (e.g., peroxidase and catalase). Due to someplants could not show any response to phytoremediation under normal growth conditions, but they could be capacitated for remediation by manipulating their biochemistry using nanoparticles (Verma et al. 2021).

\section{Applications of nano-remediation}

The remediation of soil and water based on the nanomaterials through the plants (phytonano-remediation) or the biological agents (nanobioremediation) may depend on different factors including depth of pollution and the kind of pollutants, $\mathrm{pH}$, temperature, soil or water properties, and metal or pollutant species. The nano-remediation is a remediation method in which nanomaterials could be included in presence of plants or biological agents. Therefore, there is a need for a complete knowledge of plant physiology, biochemistry and degradation of pollutants as well as a suitable assessment of probable collaborative impacts (Verma et al. 2021). As nanomaterials has applied to almost all fundamental disciplines including agriculture (Attia and Elsheery 2020), medicine (Saxena et al. 2020), and food technology (Thangadurai et al. 2020), nanomaterials also have been used in environmental remediation (Guerra et al. 2018; Das et al. 2019; Ken and Sinha 2020; Mallikarjunaiah et al. 2020; Qian et al. 2020; Agrawal and Verma, 2021; Trivedia and Bergi, 2021). The nanotechnology could be used for in situ remediation of polluted soils through the following mechanisms immobilization, Fenton and Fenton-like oxidation, photocatalytic degradation, reduction reaction and various combinations (Qian et al. 2020). 
Concerning the applications of nanoparticles in environmental remediation, researchers have shown great concern in the utilization of nanotechnology in environmental remediation. There is a crucial importance for using the green synthesis of nanoparticles in this remediation due to itsability to provide a clean, environment friendly method, nontoxic and producing nanoparticles by eliminating toxic by-products and toxic precursors as well as it actsas an effective and sustainable technique for environmental remediation (Das et al. 2019). In general, the most important applications of nanomaterials in remediation may include detecting and removing heavy metals from soil and water, degradation of dyes in the industrial wastewater, and degradation and removing hydrocarbons (Das et al. 2019). Guerra et al. (2018) classified the nanomaterials used for environmental remediation into three main categories to include inorganic (metal and metal oxide-based nanomaterials like Ag-NPs, $\mathrm{TiO}_{2}$-NPs, iron-based nanoparticles), carbon-based (fullerene $\mathrm{C}_{60}$, fullerene $\mathrm{C}_{540}$, graphene, single-walled nanotubes and multiwalled nanotubes), polymeric-based materials (e.g., amphiphilic polyurethane NPs, polyaminemodified cellulose and polymer nanocomposites) and silica nanomaterials or silica-graphene porous nanocomposites (Thakkar and Malfatti, 2021). Important nanomaterials used in soil and water remediation include nano-silica (Jeelani et al. 2020) and zero-valent iron nanoparticles (Galdames et al. 2020).

\subsection{Nano-silica}

Silica nanoparticles or nano-silica $\left(\mathrm{SiO}_{2}-\right.$ NPs) have become one of the most important nanoparticles, already used as nano-structuring, optical imaging agents and drug delivery as well as in environment cleanup due to its immensely stable and less toxic (Jeelani et al. 2020). Silica nanoparticles also have been applied for the environmental remediation from pollutants like to reduce the radioactive compounds and heavy metals into soil and water, removing of nonmetals,metalsand radioactive elements as well as water purification (Jeelani et al. 2020). In an incubation Lab experiment, surface-modified nano-silica was used tostabilize $\mathrm{Cd}$ in polluted soils, and the maximum stabilization efficiency of Cd reached $91.21 \%$ under control both of moisture of soil and particle size (Wang et al. 2020a). A field experiment was carried out using surfacemodified nano-silicato stabilize a Cd polluted soil under field conditions, which at applied rate of $1 \%$ reduced the $\mathrm{Cd}$ contents in maize and wheatgrains $42.87 \%$ and $47.95 \%$, respectively (Wang et al. 2020a). Nano-silica could be used as a new type of silicon fertilizer and as a carrier material, which has good environmental compatibility with soil. Nano-silica could increase the rice yield as fertilizer, but it has a poor adsorption capability towards the heavy metal ions in soils. Therefore, some researchers graft silane coupling agent onto the surface of silica to increase the ability of adsorption towards heavy metals (Cao et al. 2020). Some case studies for phyto- and bio-nanoremediation of nano-silica are listed in Table 1.

\subsection{Nano-zero-valent iron}

The nano-zero-valent of some metals could be used in removing pollutants from soil and water such as thallium ( $\mathrm{Tl})$ removal by nano-zero-valent Mn (Li et al. 2020), lead (Pb) by nano-zero-valent Sn (Mahmoud and Abdelwahab 2021), antibiotics

TABLE 1. Some studies on the role of nano-silica in removingpollutants from soil and water

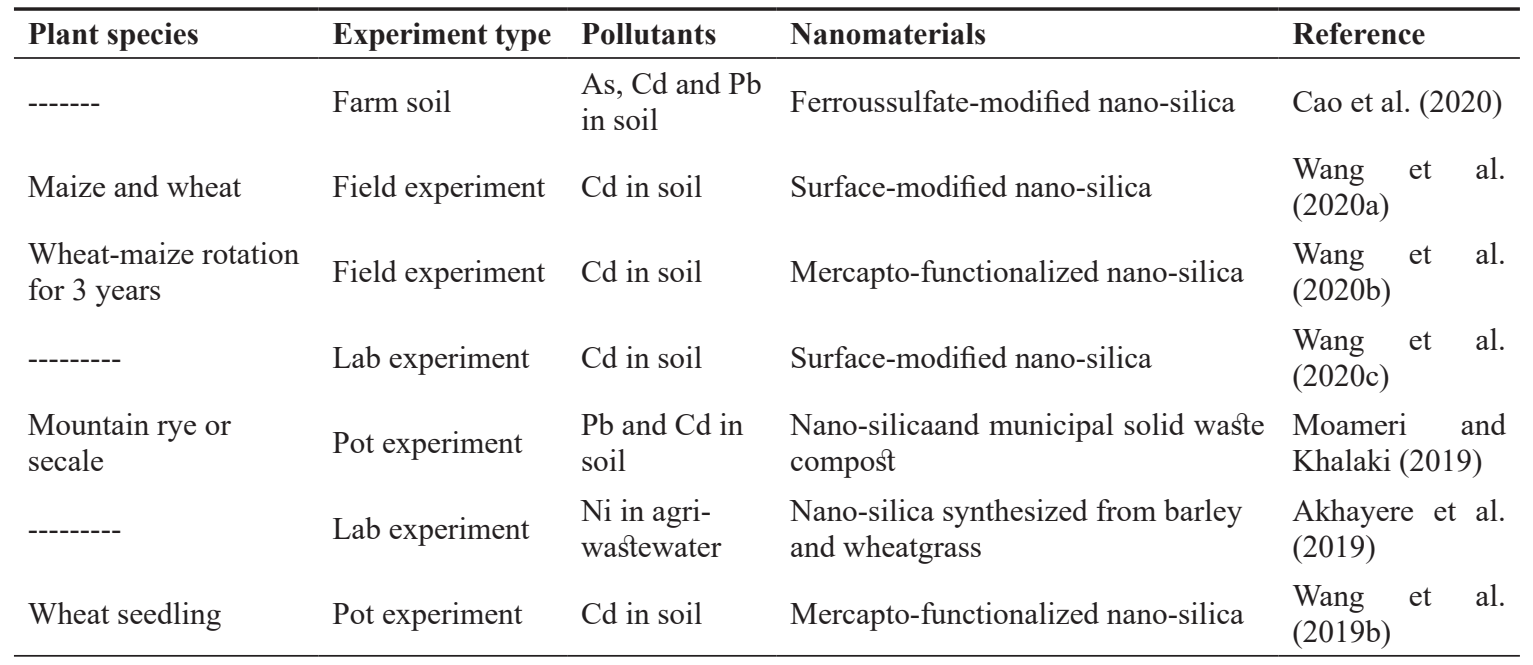


by nano-zero-valent tungsten (Ye et al. 2020), antibiotic sulfamethazine by nanosized zerovalent copper (Zhang et al. 2020) and uranium (U-VI) by nano zero-valent iron (Zhang et al. 2021). The nano-zero-valent iron (nZVI) or iron nanoparticles is a promising remediator material could be used in environmental remediation. Iron nanoparticles are a type of iron-based materials have distinguished characterization including low toxicity, high iron source availability, high reactivity and attractive magnetic properties (magnetic adsorbents), which may support the adsorption through remediation (Fig. 1). The nZVI also could achieve both the adsorption of pollutants and reduction or oxidation through the induction of reactive oxygen species generated in aqueous solution. These nanoparticles also have been successfully applied to remove various pollutants including heavy metal ions (Xu et al. 2019; Soto-Hidalgo et al. 2020), dyes and textile compounds (Puthukkara et al. 2020) and organic compounds (Peng et al. 2020). Some case studies for phyto- and bio-nano-remediation of nanozero-valent of iron are listed in Table 2.
Therefore, the most critical points regarding the pollution of soil and water resources, which is considered one of the most serious obstacles facing all countries worldwide. Many environmental risks could be noticed, which needed mitigating through many remediation methods to remove or degrade different contaminants in soil and groundwater, including the phyto- and bio-nanoremediation. In this context, it could present a case study for air pollution and cultivation of banana in Egypt. The source of air pollution was red brick factory, whose pollutants injured plant leaves (brown spot on banana leaves) after fall down the dew drops in the morning (Fig. 2). This story may include some other sides, which interact with pollution (salinity of irrigation water and calcium deficiency). The source of irrigation water is groundwater from wells at depth around $100 \mathrm{~m}$; its salinity increased year by year causing a lot of problems for cultivated plants in this area (Fig. 3 and 4).

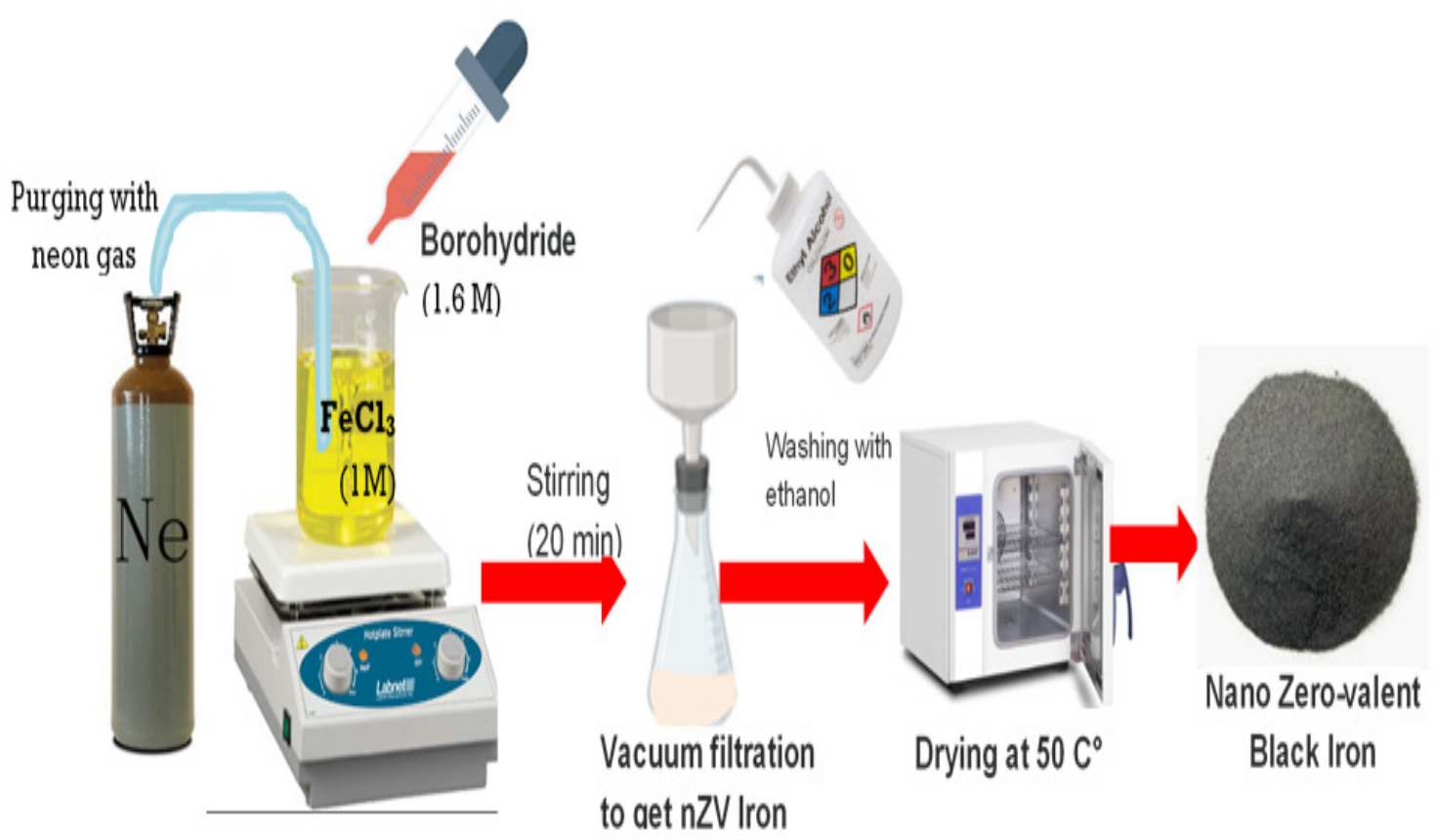

Fig. 1. Production of nano zero-valent iron (nZVI) by the reductive precipitation process using borohydride as a reducing agent, neon gas was used to keep the reductive environment. Precipitated nZVI was dried at 50 $\mathrm{C}^{\circ}$ then kept under a thin layer of ethanol to prevent oxidation 
TABLE 2. Some studies on the role of nano-zero-valent iron in removing pollutants

\begin{tabular}{|c|c|c|c|c|}
\hline Plant species & Experiment type & Pollutants & Nanomaterials & Reference \\
\hline -------- & Batch experiment & $\begin{array}{l}\text { Organic contami- } \\
\text { nants }\end{array}$ & $\begin{array}{l}\text { Porous silicate supported } \\
\text { micro-nano zero-valent } \\
\text { iron }\end{array}$ & Gao et al. (2021) \\
\hline-4 & Batch experiment & $\mathrm{Cr}(\mathrm{VI})$ in water & $\begin{array}{l}\text { Zero-valent iron nanopar- } \\
\text { ticles }\end{array}$ & Wu et al. (2021) \\
\hline -------- & Batch experiments & $\begin{array}{l}\text { Chlorophenol } \\
\text { and } \mathrm{Cr}(\mathrm{VI})\end{array}$ & $\begin{array}{l}\text { Modified nanoscalezero- } \\
\text { valent iron }\end{array}$ & Xie et al. (2021) \\
\hline & $\begin{array}{l}\text { Batch sorption } \\
\text { experiments }\end{array}$ & $\begin{array}{l}\text { U-VI in sewage } \\
\text { water }\end{array}$ & $\begin{array}{l}\text { Activated biochar-loaded } \\
\text { nano zero-valent iron }\end{array}$ & $\begin{array}{l}\text { Zhang et al. } \\
(2021)\end{array}$ \\
\hline $\begin{array}{l}\text { Seeds of watercress (Nas- } \\
\text { turtium officinale) }\end{array}$ & $\begin{array}{l}\text { batch experiment, } \\
\text { petri dishes }\end{array}$ & As-polluted soils & $\begin{array}{l}\text { Zero-valent iron and goe- } \\
\text { thite nanoparticles }\end{array}$ & $\begin{array}{l}\text { Baragaňo et al. } \\
(2020)\end{array}$ \\
\hline $\begin{array}{l}\text { Rice (Oryza sativa) } \\
\text { seedlings }\end{array}$ & Pot experiment & $\mathrm{Cd}$ in soil & Nanoscalezero-valent iron & $\begin{array}{l}\text { Guha et al. } \\
(2020)\end{array}$ \\
\hline & $\begin{array}{l}\text { Lab work in a bal- } \\
\text { loon flask }\end{array}$ & $\begin{array}{l}\text { Organic As- pol- } \\
\text { lutants }\end{array}$ & $\begin{array}{l}\mathrm{SiO}_{2} \text {-coated nano-zero- } \\
\text { valent iron }\end{array}$ & Lv et al. (2020) \\
\hline 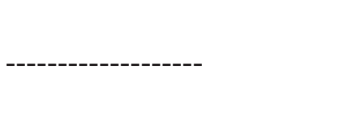 & Batch experiment & As(III) & $\begin{array}{l}\text { Nanoscalezero-valent iron- } \\
\text { encapsulated in porous } \\
\text { zeolite- } \mathrm{TiO}_{2}\end{array}$ & $\begin{array}{l}\text { Madan et al. } \\
(2020)\end{array}$ \\
\hline & $\begin{array}{l}\text { Granulation experi- } \\
\text { ment }\end{array}$ & $\mathrm{Cr}(\mathrm{VI})$ in soil & $\begin{array}{l}\text { Nanoscalezero-valent } \\
\text { iron supported on vinegar } \\
\text { residue }\end{array}$ & Pei et al. (2020) \\
\hline $\begin{array}{l}\text { Blackmangrove (Avicen- } \\
\text { nia germinans) }\end{array}$ & $\begin{array}{l}\text { Lab system for } \\
\text { remediation }\end{array}$ & $\begin{array}{l}\text { As, } \mathrm{Cd} \text { and } \mathrm{Pb} \\
\text { in soil }\end{array}$ & Nano-zero-valent iron & $\begin{array}{l}\text { Soto-Hidalgo et } \\
\text { al. }(2020)\end{array}$ \\
\hline -------- & Batch experiment & $\begin{array}{l}\mathrm{Cr}(\mathrm{VI}) \text { in waste- } \\
\text { water }\end{array}$ & $\begin{array}{l}\text { Nano zero-valentiron/car- } \\
\text { bon/alginate composite gel }\end{array}$ & Wen et al. (2020) \\
\hline $\begin{array}{l}\text { Rice (Oryza sativa) } \\
\text { seedlings }\end{array}$ & $\begin{array}{l}\text { Batch experiment, } \\
\text { petri dishes }\end{array}$ & $\mathrm{Cr}(\mathrm{VI})$ & $\begin{array}{l}\text { Polyethyleneglycol- } \\
\text { stabilized nano zero-valent } \\
\text { iron supported by biochar }\end{array}$ & Wu et al. (2020) \\
\hline & $\begin{array}{l}\text { Lab system for } \\
\text { reclaimed water }\end{array}$ & $\begin{array}{l}\text { Fluorogluco- } \\
\text { corticoids }\end{array}$ & $\begin{array}{l}\text { Nanozero-valent iron- } \\
\text { modified biochar }\end{array}$ & $\begin{array}{l}\text { Xiang et al. } \\
(2020)\end{array}$ \\
\hline . & Batch experiment & $\begin{array}{l}\text { Iodinated } \\
\text { contrast media } \\
\text { diatrizoate }\end{array}$ & $\begin{array}{l}\text { Sulfidemodified nano-sized } \\
\text { zero-valent iron }\end{array}$ & $\begin{array}{l}\text { Zhou et al. } \\
(2020)\end{array}$ \\
\hline & $\begin{array}{l}\text { Column flushing } \\
\text { technique }\end{array}$ & Diesel oil in soil & $\begin{array}{l}\text { Zero-valent iron and iron } \\
\text { oxide nanoparticles }\end{array}$ & $\begin{array}{l}\text { Karthick et al. } \\
\text { (2019) }\end{array}$ \\
\hline & Pot experiment & $\begin{array}{l}\text { Cr in alkaline } \\
\text { soil }\end{array}$ & $\begin{array}{l}\text { Multiloadednano-zero- } \\
\text { valent iron }\end{array}$ & Hou et al. (2019) \\
\hline - & Column experiment & $\begin{array}{l}\mathrm{Cr}(\mathrm{VI}) \text { in } \\
\text { groundwater }\end{array}$ & $\begin{array}{l}\text { Dispersed-sodiumalginate } \\
\text { nano-zero-valent iron }\end{array}$ & Li et al. (2019) \\
\hline $\begin{array}{l}\text { Broadbean and (Brassica } \\
\text { chinesis L.) }\end{array}$ & Pot experiment & $\begin{array}{l}\mathrm{Cd}, \mathrm{Cr} \text {, and } \mathrm{Pb} \\
\text { in soil }\end{array}$ & $\begin{array}{l}\text { Nano-zero-valent ironmod- } \\
\text { ified attapulgite clay }\end{array}$ & Xu et al. (2019) \\
\hline ------- & Batch experiments & $\begin{array}{l}\text { Cd in aqueous } \\
\text { solution }\end{array}$ & $\begin{array}{l}\text { Porousbiochar loaded with } \\
\text { nano-zero-valent iron/ } \\
\text { nano-a-hydroxy-iron oxide }\end{array}$ & Zhu et al. (2019) \\
\hline
\end{tabular}

Env. Biodiv. Soil Security Vol. 4 (2020) 

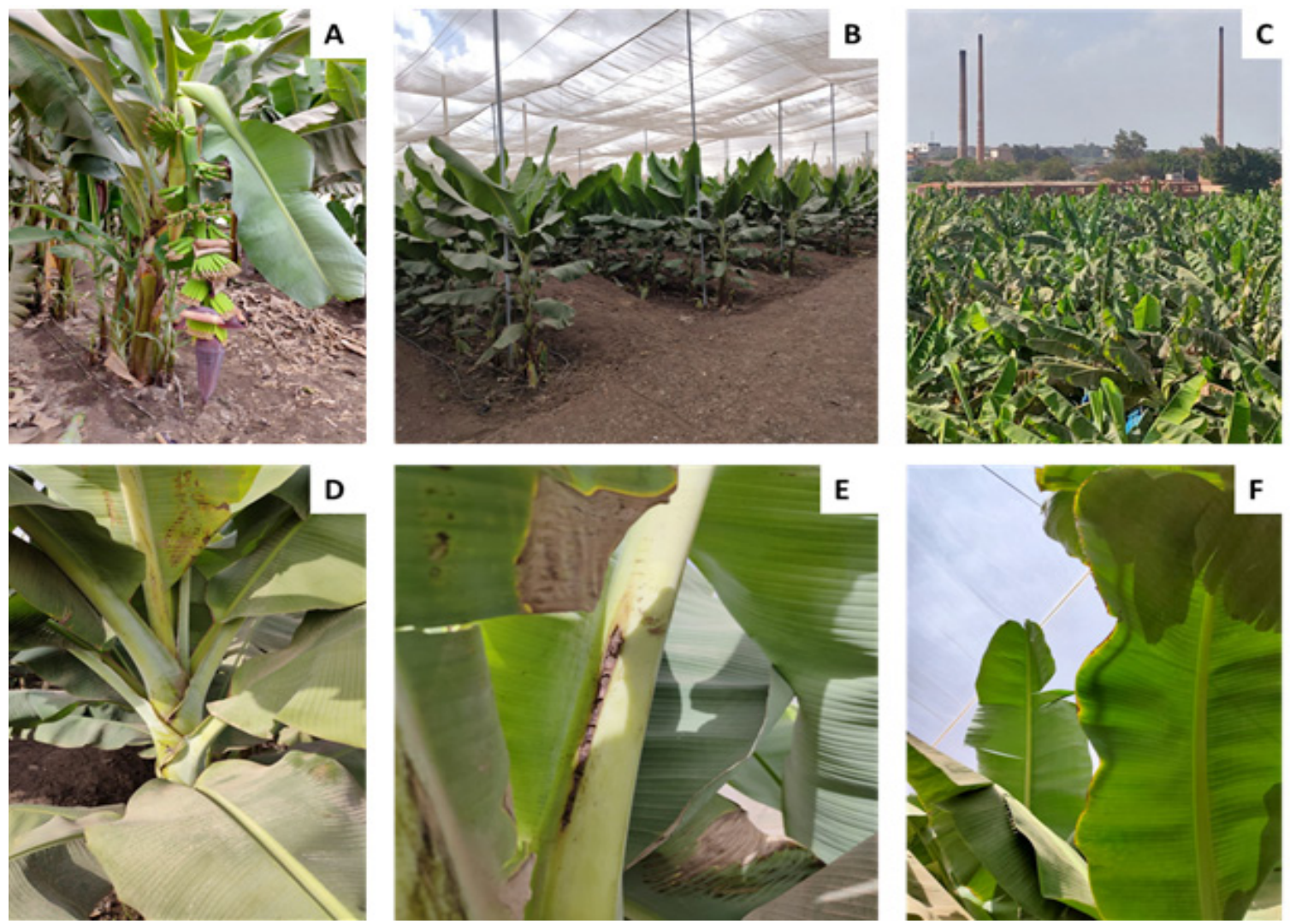

Fig. 2. Effect of smoke pollution resulted from red brick factory on banana growth:(A) normal field of banana, which far from pollution,(B) protected banana from pollution under greenhouse conditions, $(C)$ the field of banana near or close to the source of pollution or the factory,(D) symptoms of pollution injury which represents in brown spot on banana leaves and(E) burning leaves and midrib or(F) burning margin of leaves.
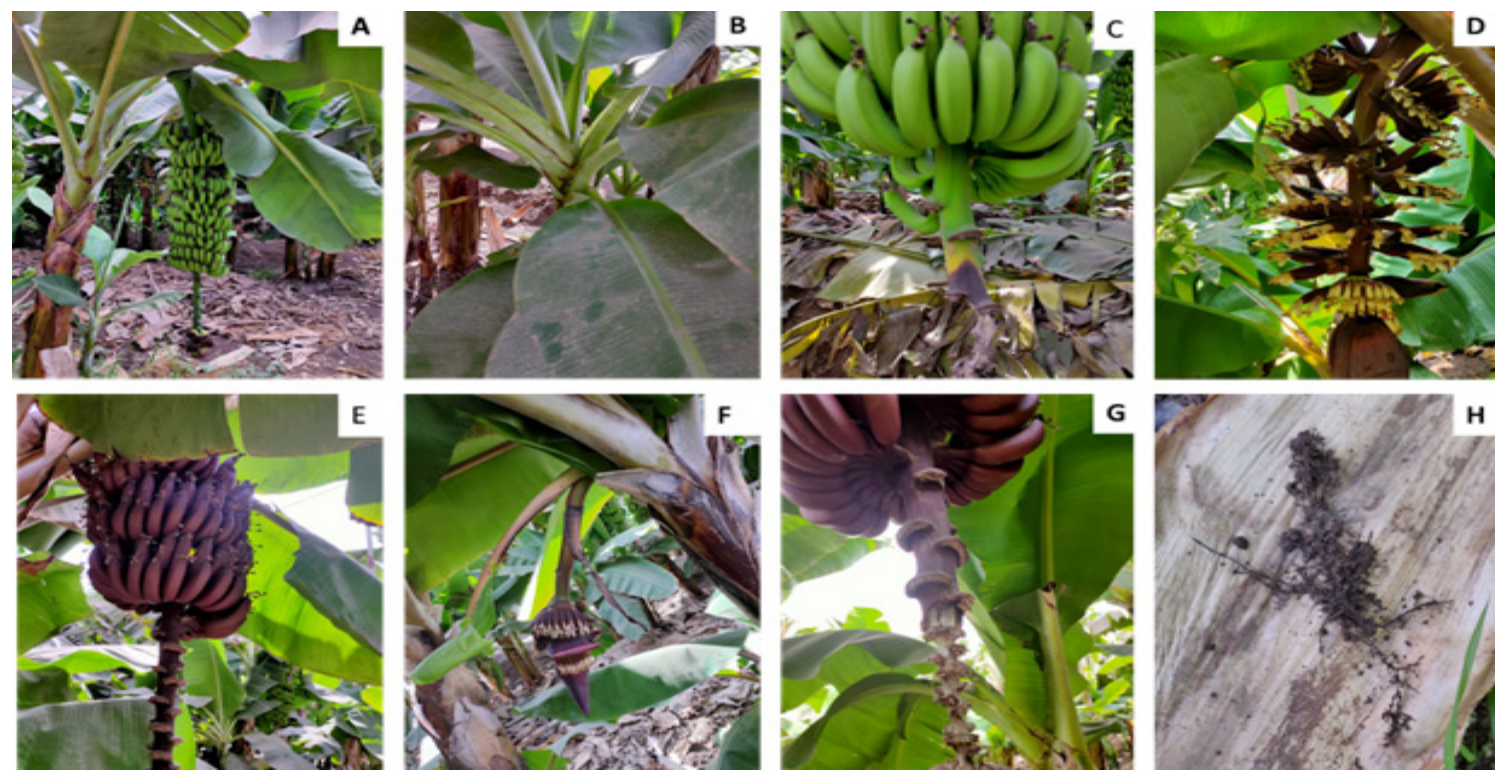

Fig. 3. Growth and fruiting of banana as influenced by air pollution andwater excess: (A) normal yellow banana plant has excellent bunch and sucker,(B) pollution symptoms here may represent in abnormal sucker, which has crowded leaves in the top plant, $(C)$ rot of yellow banana bunch before fruit ripening (D) red banana plant has normal flowers and (E) red banana plant has normal bunch, where (F) abnormal plant has little flowers in $(G)$ rot of red banana bunch and $(H)$ root rot for water excess 

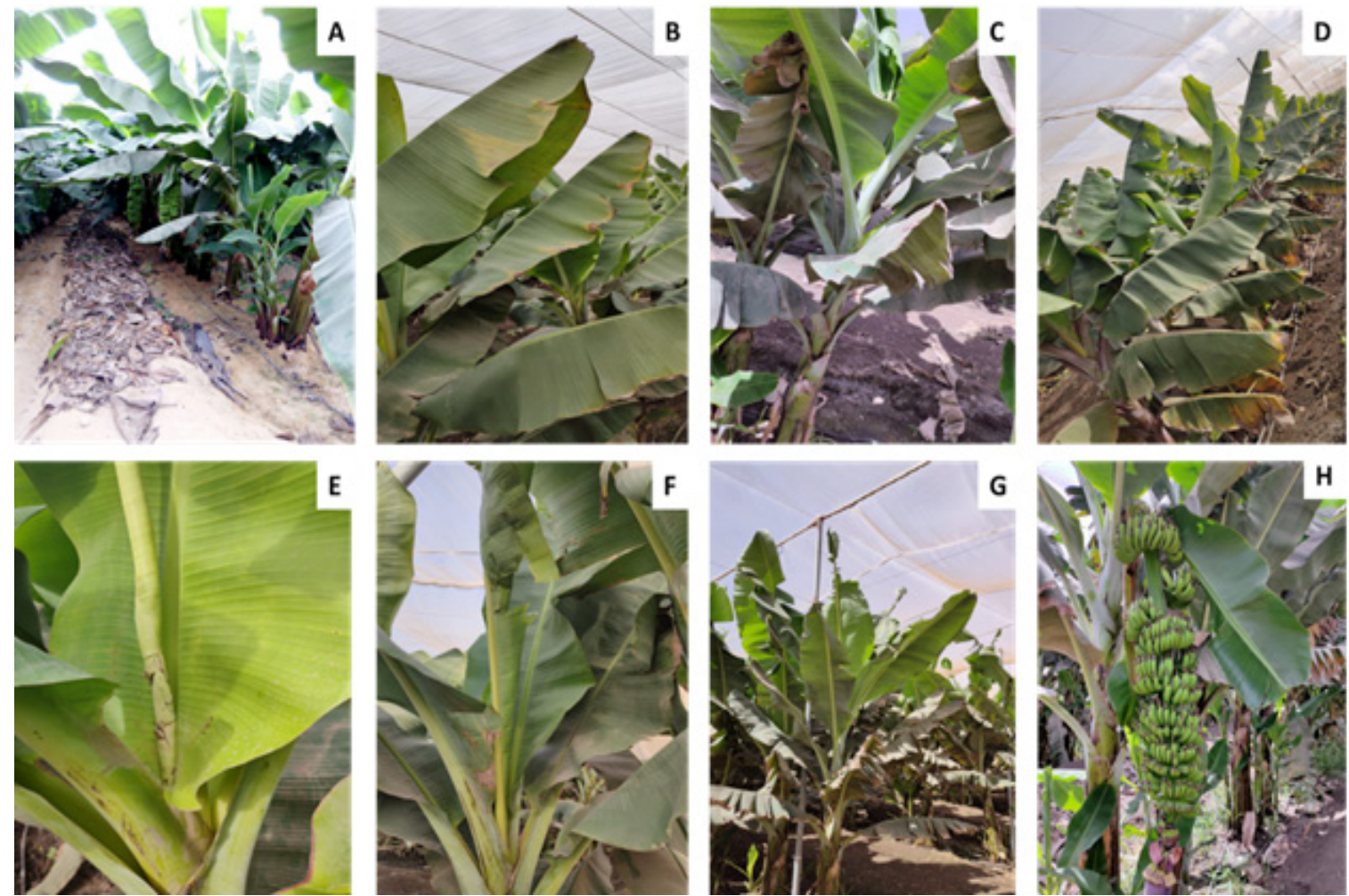

Fig. 4. The impact of pollution on banana may include another side (i.e., salinity of irrigation water= $950-850$ $\mathrm{mg} \mathrm{l}^{-1}$ ), where represent in salinity and calcium deficiency on banana growth (although $\mathrm{Ca}$ in soil is high content): (A) healthy banana plants in excellent field,(B) changes or water salinity symptoms onthe color of banana leaves, $(C$ and $D)$ burning the leaves from water salinity, but for calcium deficiency youngest leaves are torn (E and F), new leaves lost leaf blade $(G)$ andbanana figures are short for calcium deficiency $(H)$.

\section{Conclusion}

To address the goals of increasing sustainable agriculture, the agro-pollutants should be remediated using different techniques or approaches. A wide range of these techniques could be employed in soil and water remediation, including the use of nanoparticles in phytoremediation and bioremediation. The combination of both bioremediation and nanotechnology, which produce thenano-phytoremediation and nano-bioremediation hasalso become popular in recent years. However, the new approaches within each of these technologies still also need to be explored in order to overcome the issues of eachexisting methodology. The methods of nano-bioremediation and nano-phytoremediation are still having several key challenges, such as the acceptable cost, biodegradability, nontoxicity, recyclability, high transformation/elimination capacity of the target compounds, ease of synthesis from a green chemistry perspective, and the potential for recovery after use or regeneration. There are several obstacles to overcome in implementing technology of nano-phytoremediation for the common usage for which science is constantly developing, refining, and making breakthroughs. The integrated nano-phytoremediation technology may hold great promises towards environmental remediation; however, uncertain fate of nanoparticles in the agroecosystems and toxicity towards nontargeted species is not fully understood and yet to be explored further. Several open questions still needed to be investigated concerning the nano-remediation based on the characterization of contaminated soil or water environment, nature of nanomaterials and its concentration, nature and properties of contaminated site, beside the $\mathrm{pH}$, temperature of environment.

\section{Ethics approval and consent to participate}

This article does not contain any studies with human participants or animals performed by any of the authors.

\section{Author contribution}

This study was designed and implementedby authors,where all authors contributed in writing the manuscript, interpreting information presented and have read and agreed to the version of the manuscript. 


\section{Consent for publication} tion.

All authors declare their consent for publica-

\section{Conflicts of Interest}

The authors declare that there is no conflict of interest.

\section{Acknowledgement}

The authors thank the staff members of Physiology and Breeding of Horticultural Crops Laboratory, Dept. of Horticulture, Fac. of Agric., Kafrelsheikh University, Kafr El-Sheikh, Egypt for conducting the most parameters as well as they helped in completing this work.

\section{References}

Agrawal K, Verma P (2021) The Interest in Nanotechnology: A Step Towards Bioremediation. In: M. P. Shah (Ed.) Removal of Emerging Contaminants Through Microbial Processes, https://doi.org/10.1007/978-981-15-5901-3_13, pp: 265 - 282. Springer Nature Singapore Pte Ltd.

Ahamad A, Madhav S, Singh AK, Kumar A, Singh P (2020). Types of Water Pollutants: Conventional and Emerging. In: D. Pooja et al. (Eds.), Sensors in Water Pollutants Monitoring: Role of Material, Advanced Functional Materials and Sensors, https://doi.org/10.1007/978-981-15-0671-0_3, pp. 21 - 42. Springer Nature Singapore Pte Ltd.

Ahmad A, Ghufran R, Al-Hosni TK (2019). Bioavailability of zinc oxide nano particle with fly ash soil for the remediation of metals by Parthenium hysterophorus. Journal of Environmental Health Science and Engineering, 17:1195-1203.

Akhayere E, Essien EA, Kavaz D (2019) Effective and reusable nano-silica synthesized from barley and wheat grass for the removal of nickel from agricultural wastewater. Environmental Science and Pollution Research, 26: 25802-25813. https:// doi.org/10.1007/s11356-019-05759-x

Attia TMS, Elsheery NI (2020). Nanomaterials: Scope, Applications, and Challenges in Agriculture and Soil Reclamation. In: S. Hayat et al. (Eds.), Sustainable Agriculture Reviews 41, https://doi. org/10.1007/978-3-030-33996-8_1, pp. 1 - 33. Springer Nature Switzerland AG

Baragaňo D, Alonso J, Gallego JR, Lobo MC, Gil-Díaz M (2020) Zero valent iron and goethite nanoparticles as new promising remediation techniques for Aspolluted soils. Chemosphere 238, 124624. https:// doi.org/10.1016/j.chemosphere.2019.124624

Bhati M, Rai R (2018) Nano-phytoremediation Application for Water Contamination. In: A. A. Ansari et al. (Eds.), Phytoremediation, https://doi. org/10.1007/978-3-319-99651-6_19, pp: 441 452. Springer Nature Switzerland AG

Bhuiyan MAH, Karmaker SC, Bodrud-Doza M, Abdur Rakib M, Saha BB (2021) Enrichment, sources and ecological risk mapping of heavy metals in agricultural soils of dhaka district employing SOM, PMF and GIS methods. Chemosphere 263, 128339. $\quad$ https://doi.org/10.1016/j. chemosphere.2020.128339

Bolan N, Sarkar B, Yan Y, Li Q, Wijesekara H, Kannan K, Tsang DCW, Schauerte M, Bosch J, Noll H, Ok YS, Scheckel K, Kumpiene J, Gobindlal K, Kah M, Sperry J, Kirkham MB, Wang H, Tsang YF, Hou D, Rinklebe J (2021) Remediation of poly- and perfluoroalkyl substances (PFAS) contaminated soils - To mobilize or to immobilize or to degrade? Journal of Hazardous Materials 401, 123892. https://doi.org/10.1016/j.jhazmat.2020.123892

Borah D, Kennedy B, Gopalakrishnan S, Chithonirai A, Nooruddin T (2020) Bioremediation and Biomass Production with the Green Microalga Chlorococcum humicola and Textile Mill Effluent (TE). Proc. Natl. Acad. Sci., India, Sect. B Biol. Sci. (Apr-June 2020) 90 (2): 415-423. https://doi. org/10.1007/s40011-019-01112-x

Borah P, Kumar M, Devi P (2020). Types of inorganic pollutants: metals/metalloids, acids, and organic forms. In: P Devi, P Singh and SK Kansal (Eds.), Inorganic Pollutants in Water, DOI: https://doi. org/10.1016/B978-0-12-818965-8.00002-0, pp: 17 -31 . Elsevier Inc.

Butu M, Stef R, Corneanu M, Butnariu M (2020). Mycoremediation: A Sustainable Approach for Pesticide Pollution Abatement. In: R. A. Bhat et al. (Eds.), Bioremediation and Biotechnology, Vol 2, https://doi.org/10.1007/978-3-030-40333-1_5, pp: 73 - 96. Springer Nature Switzerland AG

Cai Z, Zhao X, Duan J, Zhao D, Dang Z, Lin Z (2020) Remediation of soil and groundwater contaminated with organic chemicals using stabilized nanoparticles: Lessons from the past two decades. Front. Environ. Sci. Eng. 14 (5): 84. https://doi. org/10.1007/s11783-020-1263-8

Cao P, Qiu K, Zou X, Lian M, Liu P, Niu L, Yu L, Li X, Zhang Z (2020) Mercapto propyltrimethoxysilaneand ferrous sulfate-modified nano-silica for 
immobilization of lead and cadmium as well as arsenic in heavy metal-contaminated soil. Environmental Pollution 266, 115152. https://doi. org/10.1016/j.envpol.2020.115152

Chen X, Dai Y, Fan J, Xu X, Cao X(2020). Application of iron-biochar composite in topsoil for simultaneous remediation of chromium-contaminated soil and groundwater: Immobilization mechanism and longterm stability. Journal of Hazardous Materials, https://doi.org/10.1016/j.jhazmat.2020.124226

Čvančarová M, Shahgaldian P, Corvini PF-X (2020). Enzyme-Based Nanomaterials in Bioremediation. In: J. Filip et al. (Eds.), Advanced Nano-Bio Technologies for Water and Soil Treatment, Applied Environmental Science and Engineering for a Sustainable Future, https://doi.org/10.1007/978-3030-29840-1_16, pp: 345 - 366. Springer Nature Switzerland AG

Das A, Kamle M, Bharti A, Kumar P (2019) Nanotechnology and it's applications in environmental remediation: an overview. Vegetos 32: 227-237. https://doi.org/10.1007/s42535-019$\underline{00040-5}$

Dong Y, Lin H, Zhao Y, Menzembere ERGY (2021) Remediation of vanadium-contaminated soils by the combination of natural clay mineral and humic acid. Journal of Cleaner Production 279, 123874. https://doi.org/10.1016/j.jclepro.2020.123874

Ebrahimbabaie P, Meeinkuirt W, Pichtel J (2020) Phytoremediation of engineered nanoparticles using aquatic plants: Mechanisms and practical feasibility. Journal of Environmental Sciences 93, 151-163. https://doi.org/10.1016/j.jes.2020.03.034

Galdames A, Ruiz-Rubio L, Orueta M, SánchezArzalluz M, Vilas-Vilela JL (2020) Zero-Valent Iron Nanoparticles for Soil and Groundwater Remediation. Int $J$ Environ Res Public Health. 17(16): 5817. doi: 10.3390/ijerph17165817

Gamallo M, Fernández L, Feijoo G, Moreira MT (2020). Nano-based technologies for environmental soil remediation. In: Mu. Naushad, R. Saravanan and Kumar Raju (Eds.), Nanomaterials for Sustainable Energy and Environmental Remediation. https:// doi.org/10.1016/B978-0-12-819355-6.00010-8. Elsevier Inc. pp: $307-331$.

Gao C, Yu W, Zhu Y, Wang M, Tang Z, Du L, Hu M, Fang L, Xiao X (2021). Preparation of porous silicate supported micro-nano zero-valent iron from copper slag and used as persulfate activator for removing organic contaminants. Science of the Total Environment 754, 142131. https://doi. org/10.1016/j.scitotenv.2020.142131

Gu W, Li X, Li Q, Hou Y, Zheng M, Li Y (2020) Combined remediation of polychlorinated naphthalene-contaminated soil under multiple scenarios: An integrated method of genetic engineering and environmental remediation technology. Journal of Hazardous Materials, https://doi.org/10.1016/j.jhazmat.2020.124139

Gudeppu M, Varier KM, Chinnasamy A, Thangarajan S, Balasubramanian J, Li Y, Gajendran B (2019). Nanobiotechnology Approach for the Remediation of Environmental Hazards Generated from Industrial Waste. In: R. Saravanan et al. (Eds.), Emerging Nanostructured Materials for Energy and Environmental Science, Environmental Chemistry for a Sustainable World 23, https://doi. org/10.1007/978-3-030-04474-9 13, pp: 531 561. Springer Nature Switzerland AG

Guerra FD, Attia MF, Whitehead DC, Alexis F (2018). Nanotechnology for Environmental Remediation: Materials and Applications. Molecules, 23, 1760; doi:10.3390/molecules23071760

Guha T, Barman S, Mukherjee A, Kundu R (2020). Nano-scale zero valent iron modulates $\mathrm{Fe} / \mathrm{Cd}$ transporters and immobilizes soil $\mathrm{Cd}$ for production of Cd free rice. Chemosphere 260, 127533. https:// doi.org/10.1016/j.chemosphere.2020.127533

Gupta SD, Mukherjee A, Bhattacharya J, Bhattacharya A (2018). An Overview of Agricultural Pollutants and Organic Contaminants in Groundwater of India. In: A. Mukherjee (Ed.), Groundwater of South Asia, Springer Hydrogeology, https://doi. org/10.1007/978-981-10-3889-1 15, pp: 247 255. Springer Nature Singapore Pte Ltd.

Halecký M, Kozliak E (2020). Modern Bioremediation Approaches: Use of Biosurfactants, Emulsifiers, Enzymes, Biopesticides, GMOs. In: J. Filip et al. (Eds.), Advanced Nano-Bio Technologies for Water and Soil Treatment, Applied Environmental Science and Engineering for a Sustainable Future, https://doi.org/10.1007/978-3-030-29840-1_24, pp: 495 - 526. Springer Nature Switzerland AG

He S, Li Y, Guo H, Lu L, Yang C (2019) Combined effect of ryegrass and Hyphomicrobium sp. GHH on the remediation of EE2-Cd co-contaminated soil. J. Soils Sediments. https://doi. org/10.1007/ s11368-019-02358-8.

Hou S, Wu B, Peng D, Wang Z, Wang Y, Xu H (2019) Remediation performance and mechanism of 
hexavalent chromium in alkaline soil using multilayer loaded nano-zero-valent iron. Environmental Pollution 252, 553-561. https://doi.org/10.1016/j. envpol.2019.05.083

Hu X, Huang X, Zhao H, Liu F, Wang L, Zhao X, Gao P, Li X, Ji P (2020). Possibility of Using Modified Fly Ash and Organic Fertilizers for Remediation of Heavy-Metal-Contaminated Soils, Journal of Cleaner Production, https://doi.org/10.1016/j. jclepro.2020.124713.

Jeelani PG, Mulay P, Venkat R, Ramalingam C (2020). Multifaceted Application of Silica Nanoparticles. A Review. Silicon 12:1337-1354. https://doi. org/10.1007/s12633-019-00229-y

Jesitha K and Harikumar PS (2018). Application of Nano-phytoremediation Technology for Soil Polluted with Pesticide Residues and Heavy Metals. In: A. A. Ansari et al. (Eds.), Phytoremediation, https://doi.org/10.1007/978-3-319-99651-6 18, pp: 415 - 430. Springer Nature Switzerland AG

Kalia A, Singh S (2020) Mycodecontamination of azo dyes: nanoaugmentation technologies. 3 Biotech 10: 384. https://doi.org/10.1007/s13205-020$\underline{02378-\mathrm{Z}}$

Kalsi A, Celin SM, Bhanot P, Sahai S, Sharma JG (2020). Microbial remediation approaches for explosive contaminated soil: Critical assessment of available technologies, Recent innovations and Future prospects. Environmental Technology \& Innovation 18, 100721. https://doi.org/10.1016/j. eti.2020.100721

Kanwar VS, Sharma A, Srivastav AL, Rani L (2020). Phytoremediation of toxic metals present in soil and water environment: a critical review. Environmental Science and Pollution Research https://doi.org/10.1007/s11356-020-10713-3

Karimi F, Rahimi G, Kolahchi Z (2020) Interaction effects of salinity, sewage sludge, and earthworms on the fractionations of $\mathrm{Zn}$ and $\mathrm{Cu}$, and the metals uptake by the earthworms in a $\mathrm{Zn}$ - and $\mathrm{Cu}$-contaminated calcareous soil. Environmental Science and Pollution Research, 27: 10565-10580. https://doi.org/10.1007/s11356-020-07719-2

Karthick A, Roy B, Chattopadhyay P(2019) Comparison of zero-valent iron and iron oxide nanoparticle stabilized alkyl polyglucoside phosphate foams for remediation of diesel-contaminated soils. Journal of Environmental Management 240, 93-107. https://doi.org/10.1016/j.jenvman.2019.03.088
Ken DS, Sinha A (2020) Recent developments in surface modification of nano zero-valent iron (nZVI): Remediation, toxicity and environmental impacts. Environmental Nanotechnology, Monitoring \& Management 14, 100344. https://doi.org/10.1016/j. enmm.2020.100344

Khan MI, Cheema SA, Anum S, Niazi NK, Azam M, Bashir S, Ashraf I, Qadri R (2020). Phytoremediation of Agricultural Pollutants. In: B. R. Shmaefsky (Ed.), Phytoremediation, Concepts and Strategies in Plant Sciences, https://doi. org/10.1007/978-3-030-00099-8_2, pp: 27 - 81 . Springer Nature Switzerland AG

Kim S-K, Kim J-S, Lee H, Lee H-J (2021) Abundance and characteristics of microplastics in soils with different agricultural practices: Importance of sources with internal origin and environmental fate. Journal of Hazardous Materials 403, 123997. https://doi.org/10.1016/j.jhazmat.2020.123997

Krohn C, Jin J, Wood JL, Hayden HL, Kitching M, Ryan J, Fabijanski P, Franks AE, Tang C (2021) Highly decomposed organic carbon mediates the assembly of soil communities with traits for the biodegradation of chlorinated pollutants. Journal of Hazardous Materials 404, 124077. https://doi. org/10.1016/j.jhazmat.2020.124077

Kumar M, Xiong X, He M, Tsang DCW, Gupta J, Khan E, Harrad S, Hou D, Ok YS, Bolan NS (2020a) Microplastics as pollutants in agricultural soils. Environmental Pollution 265, 114980. https://doi. org/10.1016/j.envpol.2020.114980

Kumar S, Kumari N, Karmakar S, Ankit, Singh R, Behera M, Rani A, Kumar N (2020b) Advances in Plant-Microbe-Based Remediation Approaches for Environmental Cleanup. In: R. N. Bharagava (Ed.), Emerging Eco-friendly Green Technologies for Wastewater Treatment, Microorganisms for Sustainability 18, https://doi.org/10.1007/978981-15-1390-9 5, pp: 103 - 128. Springer Nature Singapore Pte Ltd.

Kumari S, Tyagi M, Jagadevan S (2019) Mechanistic removal of environmental contaminants using biogenic nanomaterials. International Journal of Environmental Science and Technology, 16:75917606. https://doi.org/10.1007/s13762-019-02468-3

Kumwimba MN, Meng F, Iseyemi O, Moore MT, Bo Z, Tao W, Liang TJ, Ilunga L (2018) Removal of non-point source pollutants from domestic sewage and agricultural runoff by vegetated drainage ditches (VDDs): Design, mechanism, management 
strategies, and future directions. Science of the Total Environment 639, 742-759. https://doi. org/10.1016/j.scitotenv.2018.05.184

Lacalle RG, Aparicio JD, Artetxe U, Urionabarrenetxea E, Polti MA, Soto M, Garbisu C, Becerril JM (2020). Gentle remediation options for soil with mixed chromium (VI) and lindane pollution: biostimulation, bioaugmentation, phytoremediation and vermiremediation. Heliyon 6, e04550. https:// doi.org/10.1016/j.heliyon.2020.e04550

Lee BXY, Tony Hadibarata T, Yuniarto A (2020) Phytoremediation Mechanisms in Air Pollution Control: a Review. Water Air Soil Pollut 231: 437. https://doi.org/10.1007/s11270-020-04813-6

Lee SW, Kim JH, Cha SM (2020) Analysis of the relation between pollutant loading and water depth flowrate changes in a constructed wetland for agricultural nonpoint source pollution management. Ecological Engineering 152, 105841. https://doi. org/10.1016/j.ecoleng.2020.105841

Li K, Li H, Xiao T, Zhang G, Liang A, Zhang P, Lin L, Chen Z, Cao X, Long J (2020) Zero-valent manganese nanoparticles coupled with different strong oxidants for thallium removal from wastewater. Front. Environ. Sci. Eng. 14 (2): 34. https://doi.org/10.1007/s11783-019-1213-5

Li Z, Xu S, Xiao G, Qian L, Song Y (2019) Removal of hexavalent chromium from groundwater using sodium alginate dispersed nano zero-valent iron. Journal of Environmental Management 244, 3339. https://doi.org/10.1016/j.jenvman.2019.04.130

Liang S, Xi X, Ding L, Chen Q, Liu W (2019). Immobilization Mechanism of NanoHydroxyapatite on Lead in the Ryegrass Rhizosphere Soil Under Root Confinement. Bulletin of Environmental Contamination and Toxicology 103: 330-335, https://doi.org/10.1007/s00128-019-02665-3

Liao Y, Yang J (2020) Remediation of vanadium contaminated soil by nano-hydroxyapatite. Journal of Soils and Sediments, 20:1534-1544. https://doi. org/10.1007/s11368-019-02522-0

Lin S-S, Shen S-L, Zhou A, Lyu H-M (2020). Assessment and management of lake eutrophication: A case study in Lake Erhai, China, Science of the Total Environment, https://doi.org/10.1016/j. scitotenv.2020.141618

Liu Y, Xu K, Cheng J (2020) Different Nanomaterials for Soil Remediation Affect Avoidance Response and Toxicity Response in Earthworm (Eisenia fetida). Bulletin of Environmental Contamination and Toxicology, 104: 477-483. https://doi. org/10.1007/s00128-020-02823-y

Lv Y, Huang S, Huang G, Liu Y, Yang G, Lin C, Xiao G, Wang Y, Liu M (2020) Remediation of organic arsenic contaminants with heterogeneous Fenton process mediated by $\mathrm{SiO}_{2}$-coated nano zero-valent iron. Environmental Science and Pollution Research 27: 12017-12029. https://doi. org/10.1007/s11356-020-07808-2

Madan S, Shaw R, Tiwari S, Tiwari SK (2020) Enhancing corrosion stability and shelf life of nanoscale zero-valent iron via encapsulation in porous $\mathrm{Ze}-\mathrm{TiO}_{2}$ matrix: An interface for simultaneous oxidation and adsorption of As (III). Colloids and Surfaces A 607, 125381. https://doi. org/10.1016/j.colsurfa.2020.125381

Madhav S, Ahamad A, Singh AK, Kushawaha J, Chauhan JS, Sharma S, Singh P (2020) Water Pollutants: Sources and Impact on the Environment and Human Health. In: D. Pooja et al. (Eds.), Sensors in Water Pollutants Monitoring: Role of Material, Advanced Functional Materials and Sensors, https://doi.org/10.1007/978-981-15-06710_4, pp: 43 - 62. Springer Nature Singapore Pte Ltd.

Mahmoud ME, Abdelwahab MS (2021) One-step synthesis of zero-valent $\mathrm{Sn}$ nanoparticles and potential microwave remediation of lead from water. Materials Research Bulletin 134, 111090. https://doi.org/10.1016/j.materresbull.2020.111090

Mallikarjunaiah S, Pattabhiramaiah M, Metikurki B (2020). Application of Nanotechnology in the Bioremediation of Heavy Metals and Wastewater Management. In: D. Thangadurai et al. (Eds.), Nanotechnology for Food, Agriculture, and Environment, Nanotechnology in the Life Sciences, https://doi.org/10.1007/978-3-030-31938-0_13, pp: 297 - 321. Springer Nature Switzerland AG

Mishra S, Saratale GD, Ferreira LF, Bharagava RN (2019) Plant-microbe interaction: an Ecofriendly approach for the remediation of metal contaminated environments. In: Choudhury I, Hashm S (Eds.) Reference Module in Materials Science and Materials Engineering. Elsevier, Academic. https:// doi.org/10.1016/B978-0-12-803581-8.11508-5.

Moameri M, Khalaki MA (2019) Capability of Secale montanum trusted for phytoremediation of lead and cadmium in soils amended with nano-silica and municipal solid waste compost. Environ Sci Pollut 
Res. 26: 24315-24322. https://doi.org/10.1007/ $\underline{\mathrm{s} 11356-017-0544-7}$

Moameri M, Khalaki MA (2019) Capability of Secale montanum trusted for phytoremediation of lead and cadmium in soils amended with nano-silica and municipal solid waste compost. Environ Sci Pollut Res. 26: 24315-24322. https://doi.org/10.1007/ s11356-017-0544-7

Mokarram-Kashtiban S, Hosseini SM, Kouchaksaraei MT, Younesi H (2019) The impact of nanoparticles zero-valent iron (nZVI) and rhizosphere microorganisms on the phytoremediation ability of white willow and its response. Environmental Science and Pollution Research 26: 10776-10789. https://doi.org/10.1007/s11356-019-04411-y

Nasr M (2019). Environmental Perspectives of PlantMicrobe Nexus for Soil and Water Remediation. In: V. Kumar et al. (Eds.), Microbiome in Plant Health and Disease, https://doi.org/10.1007/978981-13-8495-0 18, pp: 403 - 419. Springer Nature Singapore Pte Ltd.

Nwadinigwe AO, Ugwu EC (2018) Overview of Nano-phytoremediation Applications. In: A. A. Ansari et al. (Eds.), Phytoremediation, https://doi. org/10.1007/978-3-319-99651-6_15, pp: 377 400. Springer Nature Switzerland AG

Omran BA (2021). Facing Lethal Impacts of Industrialization via Green and Sustainable Microbial Removal of Hazardous Pollutants and Nanobioremediation. In: M. P. Shah (Ed.), Removal of Emerging Contaminants Through Microbial Processes, https://doi.org/10.1007/978981-15-5901-3 7, pp: 133 - 160. Springer Nature Singapore Pte Ltd.

Pandit PR, Kumar D, Pandya L, Kumar R, Patel Z, Bhairappanavar SB, Das J (2020) Bio-nano Approaches: Green and Sustainable Treatment Technology for Textile Effluent Challenges. In: M. Shah, A. Banerjee (Eds.), Combined Application of Physico-Chemical \&Microbiological Processes for Industrial Effluent Treatment Plant, https:// doi.org/10.1007/978-981-15-0497-6_16, pp: 339 363. Springer Nature Singapore Pte Ltd.

Pei G, Zhu Y, Wen J, Pei Y, Li H (2020) Vinegar residue supported nanoscale zero-valent iron: Remediation of hexavalent chromium in soil. Environmental Pollution 256, 113407. https://doi.org/10.1016/j. envpol.2019.113407

Peng B, Zhou R, Chen Y, Tu S, Yin Y, Ye L (2020) Immobilization of nano-zero-valent irons by carboxylated cellulose nanocrystals for wastewater remediation. Front. Chem. Sci. Eng. 14 (6): 1006 1017. https://doi.org/10.1007/s11705-020-1924-y

Puthukkara PAR, Jose TS, Dinoop DS (2020). Plant Mediated Synthesis of Zero Valent Iron Nanoparticles and its Application in Water Treatment, Journal of Environmental Chemical Engineering, doi: https://doi.org/10.1016/j. jece.2020.104569

Qian Y, Qin C, Chen M, Lin S (2020) Nanotechnology in soil remediation - applications vs, implications. Ecotoxicology and Environmental Safety 201, 110815. https://doi.org/10.1016/j. ecoenv.2020.110815

Raj D, Maiti SK (2021) Brassica Juncea (L.) Czern. (Indian Mustard): A Potential Candidate for the Phytoremediation of Mercury from Soil. In: S. Kumar et al. (Eds.), Sustainability in Environmental Engineering and Science, Lecture Notes in Civil Engineering 93, https://doi.org/10.1007/978981-15-6887-9 7, pp: 67 - 72. Springer Nature Singapore Pte Ltd.

Romeh AA, Saber RAI (2020). Green nanophytoremediation and solubility improving agents for the remediation of chlorfenapyr contaminated soil and water. Journal of Environmental Management 260, 110104. https://doi. org/10.1016/j.jenvman.2020.110104

Saratovskikh EA (2020) Comparison of Impact of Residual Radioactivity Versus Pesticide-Derived Soil Pollution on Genotoxicity. Russian Journal of Physical Chemistry B, 14 (1): 59-68. DOI: 10.1134/S1990793120010285

Sarkar A, Sengupta S, Sen S (2019). Nanoparticles for Soil Remediation. In: K M Gothandam et al. (Eds.), Nanoscience and Biotechnology for Environmental Applications, Environmental Chemistry for a Sustainable World 22, https://doi.org/10.1007/9783-319-97922-9 9, pp: 249 - 262. Springer Nature Switzerland AG

Saxena G, Purchase D, Mulla SI, Saratale GD, Bharagava RN (2019) Phytoremediation of heavy metal-contaminated sites: eco-environmental concerns, field studies, sustainability issues, and future prospects. In: de Voogt P (Ed.) Reviews of environmental contamination and toxicology, Vol. 249, pp: 71-131.

Saxena SK, Nyodu R, Kumar S, Maurya VK (2020) Current Advances in Nanotechnology and Medicine. In: S. K. Saxena, S. M. P. Khurana (Eds.), Nano- 
Bio-Medicine, https://doi.org/10.1007/978-981-329898-9 1, pp: 3 - 33. Springer Nature Singapore Pte Ltd.

Semerád J, Pivokonský M, Cajthaml T (2020) NanoBioremediation: Nanoscale Zero-Valent Iron for Inorganic and Organic Contamination. In: J. Filip et al. (Eds.), Advanced Nano-Bio Technologies for Water and Soil Treatment, Applied Environmental Science and Engineering for a Sustainable Future, https://doi.org/10.1007/978-3-030-29840-1_20, pp: 425 - 433. Springer Nature Switzerland AG

Shahi MP, Kumari P, Mahobiya D, Shahi SK (2021). Nano-bioremediation of environmental contaminants: applications, challenges, and future prospects. In: Vineet Kumar, Gaurav Saxena and Maulin P. Shah (Eds.), Bioremediation for Environmental Sustainability. $\quad \underline{\text { http://dx.doi. }}$ org/10.1016/B978-0-12-820318-7.00004-6, pp: 83 - 98. Elsevier BV.

Sharma S, Pandey LM (2020) Nano-sorbents-assisted microbial bioremediation of hazardous petroleum hydrocarbons. In: Maulin P. Shah (Ed.), Removal of Toxic Pollutants Through Microbiological and Tertiary Treatment. https://doi.org/10.1016/B9780-12-821014-7.00008-3, pp: 233 - 247. Elsevier B.V.

Shigaki T (2020). Health Effects of Environmental Pollutants. In: X. Li, P. Liu (Eds.), Gut Remediation of Environmental Pollutants, https:// doi.org/10.1007/978-981-15-4759-1__1, pp: 1 - 29. Springer Nature Singapore Pte Ltd.

Singh E, Osmani RAM, Banerjee R (2020b). Nanobioremediation: An Emerging Approach for a Cleaner Environment. In: M. P. Shah (Ed.), Microbial Bioremediation \& Biodegradation, https://doi.org/10.1007/978-981-15-1812-6_12, pp: 309 - 363. Springer Nature Singapore Pte Ltd.

Singh R, Behera M, Kumar S (2020a). Nanobioremediation: An Innovative Remediation Technology for Treatment and Management of Contaminated Sites. In: R. N. Bharagava, G. Saxena (Eds.), Bioremediation of Industrial Waste for Environmental Safety, https://doi.org/10.1007/978981-13-3426-9 7, pp: 165 - 182. Springer Nature Singapore Pte Ltd.

Sinha S, Mehrotra T, Srivastava A, Srivastava A, Singh R (2020). Nanobioremediation Technologies for Potential Application in Environmental Cleanup. In: K. M. Gothandam et al. (Eds.), Environmental Biotechnology Vol. 2, Environmental Chemistry for a Sustainable World 45, https://doi. org/10.1007/978-3-030-38196-7 3, pp: 53 - 73. Springer Nature Switzerland AG

Soto-Hidalgo KT, Carrion-Huertas PJ, Kinch RT, Betancourt LE, Cabrera CR (2020). Phytonanoremediation by Avicennia Germinans (black mangrove) and Nano Zero Valent Iron for Heavy Metal Uptake from Cienaga Las Cucharillas Wetland Soils. Environmental Nanotechnology, Monitoring \& Management 14, 100363. https://doi. org/10.1016/j.enmm.2020.100363

Souza LRR, Pomarolli LC, da Veiga MAMS (2020) From classic methodologies to application of nanomaterials for soil remediation: an integrated view of methods for decontamination of toxic metal(oid)s. Environmental Science and Pollution Research 27: 10205-10227. https://doi. org/10.1007/s11356-020-08032-8

Srivastav A, Yadav KK, Yadav S, Gupta N, Singh JK, Katiyar R, Kumar V (2018) Nano-phytoremediation of Pollutants from Contaminated Soil Environment: Current Scenario and Future Prospects. In: A. A. Ansari et al. (Eds.), Phytoremediation, https://doi. org/10.1007/978-3-319-99651-6_16, pp: 383 401. Springer Nature Switzerland AG

Sudhakar MS, Aggarwal A, Sah MK (2020). Engineering biomaterials for the bioremediation: advances in nanotechnological approaches for heavy metals removal from natural resources. In: MP Shah, S Rodriguez-Couto and SS Şengör (Eds.), Emerging Technologies in Environmental Bioremediation. DOI: https://doi.org/10.1016/ B978-0-12-819860-5.00014-6, pp: 323 - 339 . Elsevier Inc.

Sundararaghavan A, Mukherjee A, Suraishkumar GK (2020). Investigating the potential use of an oleaginous bacterium, Rhodococcus opacus PD630, for nano-TiO, remediation. Environmental Science and Pollution Research (2020) 27:27394-27406. https://doi.org/10.1007/s11356-019-06388-0

Tan $\mathrm{H}$, Wang C, Li H, Peng D, Zeng C, Xu H (2020). Remediation of hexavalent chromium contaminated soil by nano-FeS coated humic acid complex in combination with $\mathrm{Cr}$-resistant microflora. Chemosphere 242, 125251. https://doi. org/10.1016/j.chemosphere.2019.125251

Thakkar SV, Malfatti L (2021). Silica-graphene porous nanocomposites for environmental remediation: A critical review. Journal of Environmental Management 278, 111519. https:// 
doi.org/10.1016/j.jenvman.2020.111519

Thangadurai D, Sangeetha J, Prasad R (2020). Nanotechnology for Food, Agriculture, and Environment. Nanotechnology in the Life Sciences Book Series, Springer Nature Switzerland AG, https://doi.org/10.1007/978-3-030-31938-0

Tran TD, Dao NT, Sasaki R, Tu MB, Dang GHM, Nguyen HG, Dang HM, Vo CH, Inigaki Y, Nguyen NV, Sakakibara Y (2020) Accelerated remediation of organochlorine pesticidecontaminated soils with phyto-Fenton approach: a field study. Environ Geochem Health https://doi.org/10.1007/s10653020-00588-1

Trivedia R, Bergi J (2021) Application of bionanoparticles in wastewater treatment. In: Maulin P. Shah (Ed.), Advanced Oxidation Processes for Effluent Treatment Plants. https:// doi.org/10.1016/B978-0-12-821011-6.00010-4, pp: $177-197$. Elsevier Inc.

Venier M, Salamova A, Hites RA (2019) How to distinguish urban vs. agricultural sources of persistent organic pollutants? Current Opinion in Environmental Science \& Health, 8: 23-28. https:// doi.org/10.1016/j.coesh.2019.01.005

Verma A, Roy A, Bharadvaja N (2021). Remediation of heavy metals using nanophytoremediation. In: Maulin P. Shah (Ed.), Advanced Oxidation Processes for Effluent Treatment Plants. https:// doi.org/10.1016/B978-0-12-821011-6.00013-X, pp: $273-296$. Elsevier Inc.

Verma P, Rawat S (2021). Rhizoremediation of Heavy Metal and Xenobiotic-Contaminated Soil: An EcoFriendly Approach. In: M. P. Shah (Ed.), Removal of Emerging Contaminants Through Microbial Processes, https://doi.org/10.1007/978-981-155901-3_5, pp: 95 - 113. Springer Nature Singapore Pte Ltd.

Wang J, Shi L, Zhai L, Zhang H, Wang S, Zou J, Shen Z, Lian C, Chen Y (2021) Analysis of the long-term effectiveness of biochar immobilization remediation on heavy metal contaminated soil and the potential environmental factors weakening the remediation effect: A review. Ecotoxicology and Environmental Safety 207, 111261. https://doi. org/10.1016/j.ecoenv.2020.111261

Wang Y, Liu Y, Zhan W, Niu L, Zou X, Zhang C, Ruan $X(2020 \mathrm{a})$ A field experiment on stabilization of $\mathrm{Cd}$ in contaminated soils by surface-modified nanosilica (SMNS) and its phyto-availability to corn and wheat. Journal of Soils and Sediments 20:91-98.
Wang Y, Liu Y, Zhan W, Zheng K, Lian M, Zhang C, Ruan X, Li T (2020b) Long-term stabilization of Cd in agricultural soil using mercapto-functionalized nano-silica (MPTS/nano-silica): A three-year field study. Ecotoxicology and Environmental Safety 197, 110600. https://doi.org/10.1016/j. ecoenv.2020.110600

Wang Y, Ma X, Wang J, Cheng S, Ren Q, Zhan W, Wang Y (2019b) Effects of Mercaptofunctionalized Nanosilica on Cd Stabilization and Uptake by Wheat Seedling (Triticum aestivum L.) in an Agricultural Soil. Bulletin of Environmental Contamination and Toxicology 103:860-864. https://doi.org/10.1007/ s00128-019-02729-4

Wang Y, O'Connor D, Shen Z, Lo IMC, Tsang DCW, Pehkonen S, Pu S, Hou D (2019a) Green synthesis of nanoparticles for the remediation of contaminated waters and soils: Constituents, synthesizing methods, and influencing factors. Journal of Cleaner Production, 226, 540e549. https://doi.org/10.1016/j.jclepro.2019.04.128

Wang Y, Zhan W, Zheng K, Liu Y, Zou X, Zhang C, Ruan X (2020c) Effect of Surface-modified Nano-silica on the Mobility and Fraction of Cd in Contaminated Agricultural Soils. Soil and Sediment Contamination: An International Journal, 29:1, 96106, DOI: 10.1080/15320383.2019.1679086

Wen R, Tu B, Guo X, Hao X, Wu X, Tao H (2020). $\mathrm{An}$ ion release controlled $\mathrm{Cr}(\mathrm{VI})$ treatment agent: Nano zero-valent iron/carbon/alginate composite gel. International Journal of Biological Macromolecules, 146, 692-704. https://doi. org/10.1016/j.ijbiomac.2019.12.168

Wu H, Wei W, Xu C, Meng Y, Bai W, Yang W, Lin A (2020) Polyethylene glycol-stabilized nano zero-valent iron supported by biochar for highly efficient removal of $\mathrm{Cr}(\mathrm{VI})$. Ecotoxicology and Environmental Safety 188, 109902. https://doi. org/10.1016/j.ecoenv.2019.109902

Wu J, Yan M, Lv S, Yin W, Bu H, Liu L, Li P, Deng H, Zheng X (2021) Preparation of highly dispersive and antioxidative nano zero-valent iron for the removal of hexavalent chromium. Chemosphere 262, 127733. $\quad$ https://doi.org/10.1016/j. chemosphere.2020.127733

Xiang Y, Rene ER, Lun X, Ma W (2020) Enhanced reductive defluorination and inhibited infiltration of fluoroglucocorticoids in a river receiving reclaimed water amended by nano zero-valent ironmodified biochar: Performance and mechanisms. 
Bioresource Technology 306, 123127. https://doi. org/10.1016/j.biortech.2020.123127

Xiao L, Liu J, Ge J (2021). Dynamic game in agriculture and industry cross-sectoral water pollution governance in developing countries. Agricultural Water Management 243, 106417. https://doi. org/10.1016/j.agwat.2020.106417

Xie J, Lei C, Chen W, Xie Q, Guo Q, Huang B (2021). Catalytic properties of transition metals modified nanoscale zero-valent iron for simultaneous removal of 4-chlorophenol and $\mathrm{Cr}(\mathrm{VI})$ : Efficacy, descriptor and reductive mechanisms. Journal of Hazardous Materials 403, 123827. https://doi. org/10.1016/j.jhazmat.2020.123827

Xu C, Qi J, Yang W, Chen Y, Yang C, He Y, Wang J, Lin A (2019) Immobilization of heavy metals in vegetable-growing soils using nano zerovalent iron modified attapulgite clay. Science of the Total Environment 686, 476-483. https://doi. org/10.1016/j.scitotenv.2019.05.330

Yang J, Sun P, Zhang X, Wei X-Y, Huang Y-P, Du W-N, Abdul Qadeer, Liu M, Huang Y (2021) Source apportionment of PAHs in roadside agricultural soils of a megacity using positive matrix factorization receptor model and compoundspecific carbon isotope analysis. Journal of Hazardous Materials 403, 123592. https://doi. org/10.1016/j.jhazmat.2020.123592

Yang Y, Liu Y, Li Z, Wang Z, Li C, Wei H (2020). Significance of soil microbe in microbialassisted phytoremediation: an effective way to enhance phytoremediation of contaminated soil. International Journal of Environmental Science and Technology 17: 2477-2484. https://doi. org/10.1007/s13762-020-02668-2

Ye Q, Xu H, Zhang J, Wang Q, Zhou P, Wang Y, Huang X, Huo X, Liu C, Lu J (2020). Enhancement of peroxymonosulfate activation for antibiotics removal by nano zero valent tungsten induced $\mathrm{Cu}(\mathrm{II}) / \mathrm{Cu}(\mathrm{I})$ redox cycles. Chemical Engineering Journal, 382, 123054. https://doi.org/10.1016/j. cej.2019.123054

Yin J, Huang G, An C, Zhang P, Xin X, Feng R (2021) Exploration of nanocellulose washing agent for the green remediation of phenanthrene-contaminated soil. Journal of Hazardous Materials, 403, 123861. https://doi.org/10.1016/j.jhazmat.2020.123861

Yogalakshmi KN, Das A, Rani G, Jaswal V, Randhawa JS (2020) Nano-bioremediation: A New Age Technology for the Treatment of Dyes in Textile
Effluents. In: G. Saxena, R. N. Bharagava (Eds.), Bioremediation of Industrial Waste for Environmental Safety, https://doi.org/10.1007/978981-13-1891-7_15, pp: 313 - 347. Springer Nature Singapore Pte Ltd.

Yu B, Peng Y, Xu J, Qin D, Gao T, Zhu H, Zuo S, Song H, Dong J (2020). Phytoremediation potential of Youngia japonica (L.) DC: a newly discovered cadmium hyperaccumulator. Environmental Science and Pollution Research, https://doi. org/10.1007/s11356-020-10853-6

Yu G, Jiang P, Fu X, Liu J, Sunahara GI, Chen Z, Xiao H, Lin F, Wang X (2020) Phytoextraction of cadmium-contaminated soil by Celosia argentea Linn.: A long-term field study. Environmental Pollution 266, 115408. https://doi.org/10.1016/j. envpol.2020.115408

Zand AD, Tabrizi AM, Heir AV (2020) The influence of association of plant growth-promoting rhizobacteria and zero-valent iron nanoparticles on removal of antimony from soil by Trifolium repens. Environmental Science and Pollution Research, https://doi.org/10.1007/s11356-020-10252-x

Zazai KG, Wani OA, Ali A, Devi M (2018) Phytoremediation and carbon sequestration potential of agroforestry systems: a review. Int $J$ Curr Microbiol App Sci 7: 2447-2457.

Zeb A, Li S, Wu J, Lian J, Liu W, Sun Y (2020) Insights into the mechanisms underlying the remediation potential of earthworms in contaminated soil: A critical review of research progress and prospects. Science of the Total Environment 740, 140145. https://doi.org/10.1016/j.scitotenv.2020.140145

Zhang Q, Wang Y, Wang Z, Zhang Z, Wang X, Yang Z (2021). Active biochar support nano zero-valent iron for efficient removal of U(VI) from sewage water. Journal of Alloys and Compounds 852, 156993. https://doi.org/10.1016/j.jallcom.2020.156993

Zhang T, Yang Y, Li X, Yu H, Wang N, Li H, Du, Jiang PY, Fan X, Zhou Z (2020). Degradation of sulfamethazine by persulfate activated with nanosized zerovalent copper in combination with ultrasonic irradiation. Separation and Purification Technology 239, 116537. https://doi.org/10.1016/j. seppur.2020.116537

Zhou G-N, Li W-Q, He C-S, Liu X-C, Ding R-R, Wang Y-X, Mu Y (2020) Enhanced hydrodeiodination of iodinated contrast medium by sulfide-modified nano-sized zero-valent iron: Kinetics, mechanisms and application prospects. Chemical Engineering 
Journal 401, 126050. https://doi.org/10.1016/j. cej. 2020.126050

Zhu L, Tong L, Zhao N, Li J, Lv Y (2019) Coupling interaction between porous biochar and nano zero valent iron/nano a-hydroxyl iron oxide improves the remediation efficiency of cadmium in aqueous solution. Chemosphere 219, 493-503. https://doi. org/10.1016/j.chemosphere.2018.12.013

Zuo PR, Liu H, Xi Y, Gu Y, Ren D, Yuan X, Huang $\mathrm{Y}$ (2020) Nano-SiO 2 combined with a surfactant enhanced phenanthrene phytoremediation by Erigeron annuus (L.). Environmental Science and Pollution Research, 27: 20538-20544. 